\title{
Bactericidal Effects of Extract Basil Leaves in In-vitro Study of Pseudomonas aeruginosa
}

\author{
Deny Febriwijaya Romadhani ${ }^{1}$, Achmad Hilman Fahmy ${ }^{1}$, Ilham Putera Alam ${ }^{1}$, Hotimah \\ Masdan Salim²*
}

${ }^{1}$ Faculty of Medicine, University of Nahdlatul Ulama, Surabaya, Indonesia

${ }^{2}$ Department of Medical Biochemistry, Faculty of Medicine, University of Nahdlatul Ulama, Surabaya, Indonesia

\section{A R T I C L E I N F O}

\section{Article history:}

Received 17 September 2020

Received in revised form 23

October 2020

Accepted 29 October 2020

Available online 31 October 2020

Keywords:

Pseudomonas aeruginosa,

Bactericidal,

Extract basil leaves

(Ocimum sanctum L.)

*) Corresponding author:

dr.hotimah@unusa.ac.id

\begin{abstract}
A B S T R A C T
Introduction: Pseudomonas aeruginosa is the most common bacterial cause of nosocomial infections. Bacteria become resistant to antibiotics by various mechanisms, including producing enzymes that can damage antibiotics, change intracellular targets from antibiotics, and efflux pumps. Basil (Ocimum sanctum L.) is a traditional plant that is usually used as ingredients that contain antibacterial compounds including flavonoids, tannins, alkaloids, and eugenol. The aim was to determine the effectiveness of extract basil leaves for inhibiting and killing the growth of Pseudomonas aeruginosa.

Methods: We administrated extract basil leaves with a concentration of $100 \%, 50 \%$, and $25 \%$ in the plate contained bacterium Pseudomonas aeruginosa. The result showed that there was no inhibition of bacterial growth in broth dilution for 8 hours and 24 hours. We continued to culture bacteria for 24 hours.

Results: : The analysis showed extract basil leaves has bactericidal effects in 8 hours and 24 hours incubation significantly $(\mathrm{p}<0.05)$. However, in 24 hours more effective as a bactericidal in $100 \%$ of concentration significantly $(\mathrm{p}<0.05)$

Conclusion: From this result, eugenol (a phenol derivative found in the ethanol extract of basil leaves) has the effect of damaging cell membranes. Phenol bonding with bacterial cell walls can disrupt the permeability of transport cell membranes, thus the bacteria will be disrupted and die.
\end{abstract}

\section{Introduction}

Pseudomonas aeruginosa is the most common bacterial cause of infection in a hospital environment. The incidence of nosocomial infections in the world caused by the bacterium Pseudomonas aeruginosa is around 10-15\%. A study conducted by WHO showed that around $8.7 \%$ of 55 hospitals from 14 countries from Europe, Middle East, Southeast Asia, and the Pacific showed a nosocomial infection. The prevalence of most nosocomial infections in the Eastern Mediterranean and Southeast Asia are 11.8\% and $10.0 \%$, while those in Europe and the Western Pacific are $7.7 \%$ and $9.0 \%$ respectively. In Indonesia, namely in Adam Malik Haji Central Hospital in Medan, nosocomial infections are quite high at $6-16 \%{ }^{1}$

Based on the data from The National Healthcare Safety Network, Pseudomonas aeruginosa was ranked after Staphylococcus aureus and Acinetobacter baumannii. Infection caused by Pseudomonas aeruginosa is difficult to treat. This is due to more strains are resistant to several antibiotics (Multidrug Resistance). Bacteria become resistant to antibiotics by various mechanisms, including by producing enzymes that can damage antibiotics, change intracellular targets from antibiotics, and efflux pumps.

Karvanen (2013) has conducted a study that showed colistin is effective against gram negative bacteria including Pseudomonas aeruginosa. Colistin is currently used by inhalation, oral and parenteral, but this drug is difficult to obtain in Indonesia and drug preparations are often used for inhalation treatment with the help of a nebulizer. ${ }^{2}$

Basil (Ocimum sanctum L.) thrives in tropical and subtropical regions, one of them is Indonesia. Basil leaves contain compounds which are antibacterial including flavonoids, tannins, alkaloids, eugenol, and others. ${ }^{3}$

Methods
This study Bacterial strains
We collected Pseudomonas aeruginosa ATCC 27853
that was provided by Balai Besar Laboratorium
Kesehatan (BBLK) Surabaya. The inoculum suspension
was obtained by taking colonies from 24 hours cultures.


The colonies were suspended in sterile $0.9 \%$ aqueous solution of $\mathrm{NaCl}$. The density was adjusted to the turbidity of a 0.5 McFarland Standard (108 colony forming unit $[\mathrm{CFU}] / \mathrm{mL}$ ).

\section{Broth dilution assay}

Broth dilution assay is one of the most basic methods for antimicrobial susceptibility testing. This procedure involved doubling dilution preparations of antimicrobial agents with concentrations of $25 \%, 50 \%, 100 \%$ in liquid growth media, then inoculated with microbes in the oculus prepared in the same medium after standardized microbial suspension dilution and adjusted to the McFarland 0.5. After mixing, the tubes in grafting were incubated (mostly without agitation) under conditions of $37^{\circ} \mathrm{C}$ for 24 hours. All tests were performed four times.

\section{Determination of MIC}

Strains of Pseudomonas aeruginosa were chosen for the in-vitro MIC and MBC study. Basil leaves extract were investigated for their MIC and MBC against the chosen isolated Pseudomonas aeruginosa strains where $1 \mathrm{ml}$ of the tested extract was used in dilution method with series of 3 tubes containing $1 \mathrm{ml}$ of Mueller Hinton broth to achieve final dilutions of $25 \%, 50 \%$, and $100 \%$. Bacterial inoculums with 0.5 McFarland Standard of the chosen isolated Pseudomonas aeruginosa were inoculated into all 3 dilutions post thorough extract mix. The inoculated tubes were 8 hours and overnight incubated at $37^{\circ} \mathrm{C}$. The highest dilution of the tested basil leaves extract to inhibit growth (no turbidity in the tube) was considered as the MIC value of this extract batch against the tested bacterial species.

\section{Determination of $\mathrm{MBC}$}

All tubes showed no visible signs of growth/turbidity (MIC and higher dilutions), loopfuls were inoculated into sterile Mueller Hinton agar plates by streak plate method. The plates were 8 hours and overnight incubated at $37^{\circ} \mathrm{C}$. The least concentration that did not show any growth of tested organisms was considered as the MBC value of the tested extract against the tested bacterial.

\section{Analysis statistics}

The values of inhibition and bactericidal were given as mean \pm standard deviation (SD). The result were analyzed by Kruskall-Wallis followed by MannWhitney Test, using IBM SPSS Statistics 24 for Windows. The results, if showing $\mathrm{p}<0.05$, then it was considered statistically significant.

\section{Results \\ The Effects of Extract Basil Leaves in Minimum Inhibitory Concentration}

The antibacterial activity of the basil leaves extract tested against Pseudomonas aeruginosa showed no any bacterial inhibition in all concentration and all incubation. There was no growth in the bacteria indicated by the clear appearance at all concentrations, except positive controls containing bacteria and antibiotics, and also negative controls, which only contained the bacterium Pseudomonas aeruginosa according to what is shown in Pictures A and B. This occurred at all times of treatment which were 8 hours and 24 hours incubation.

\section{The Effects of Extract Basil Leaves in Minimum Bactericidal Concentration}

Then the bacteria were inoculated, the results showed any growth in all concentration with 8 hours and 24 hours incubation, but the least growth was in 24 hours. This bacterial growth was seen by the presence of bacterial colonies on the plate shown in Figures $C$ and D. Then these results were supported by statistical analysis which showed extract of basil leaves had bactericidal effects in 8 hours and 24 hours incubation significantly $(\mathrm{p}<0.05)$. However, in 24 hours more effective as a bactericidal in $100 \%$ of concentration significantly $(\mathrm{p}<0.05)$.

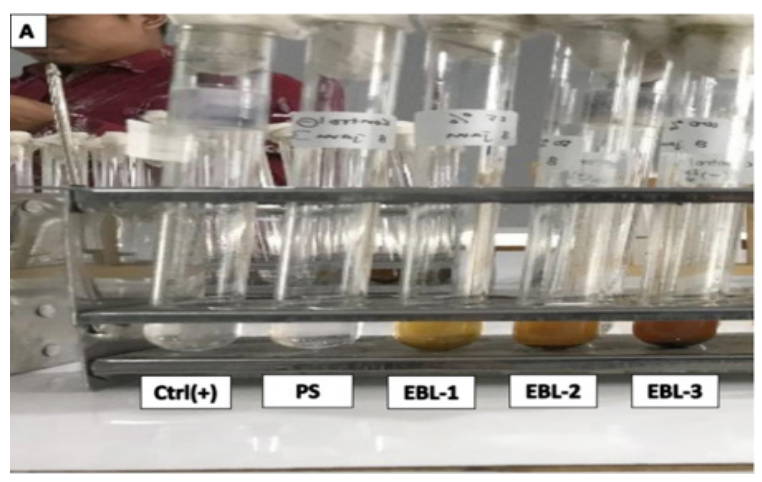

Figure A. Results of the effect of extract basil leaves in minimum inhibitory consentration with broth methods for 8 hours. Ctrl (+); positive controls contained bacteria Pseudomonas aeruginosa and antibiotics, PS; negative controls contained bacteria Pseudomonas aeruginosa only, EBL-1; extract basil leaves with 25\% concentration, EBL2 ; extract basil leaves with $50 \%$ concentration, EBL-3; extract basil leaves with $100 \%$ concentration.

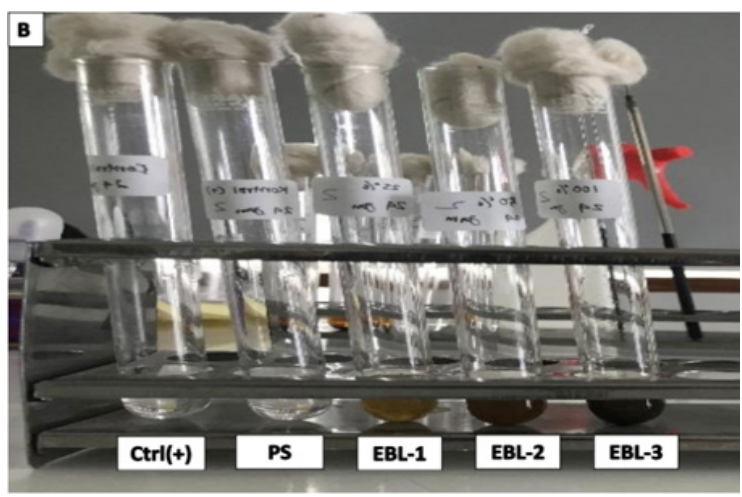

Figure B. Results of the effect of extract basil leaves in minimum inhibitory consentration with broth dilution for 24 hours. Ctrl $(+)$; positive controls contained bacteria Pseudomonas aeruginosa and antibiotics, PS; negative controls contained bacteria Pseudomonas aeruginosa only, EBL-1; extract basil leaves with $25 \%$ concentration, EBL2 ; extract basil leaves with $50 \%$ concentration, EBL-3; extract basil leaves with $100 \%$ concentration. 


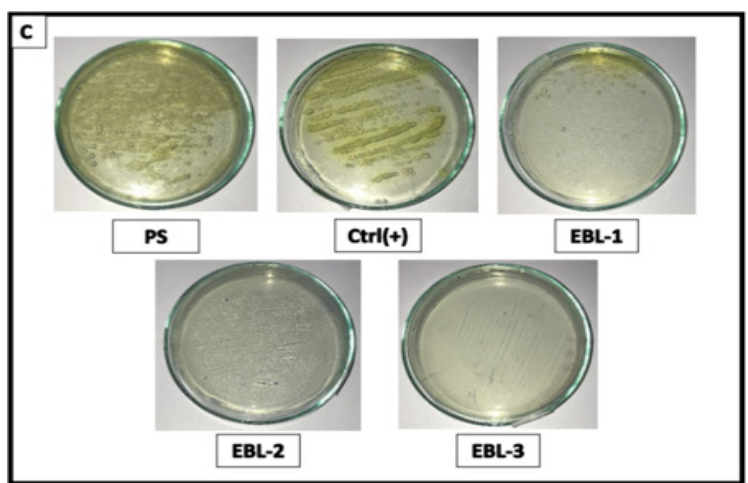

Figure C. Results of the effect of extract basil leaves in minimum bactericidal consentration with broth methods for 8 hours. Ctrl $(+)$; positive controls contained bacteria Pseudomonas aeruginosa and antibiotics, PS; negative controls contained bacteria Pseudomonas aeruginosa only, EBL-1; extract basil leaves with $25 \%$ concentration, EBL2 ; extract basil leaves with $50 \%$ concentration, EBL-3; extract basil leaves with $100 \%$ concentration.

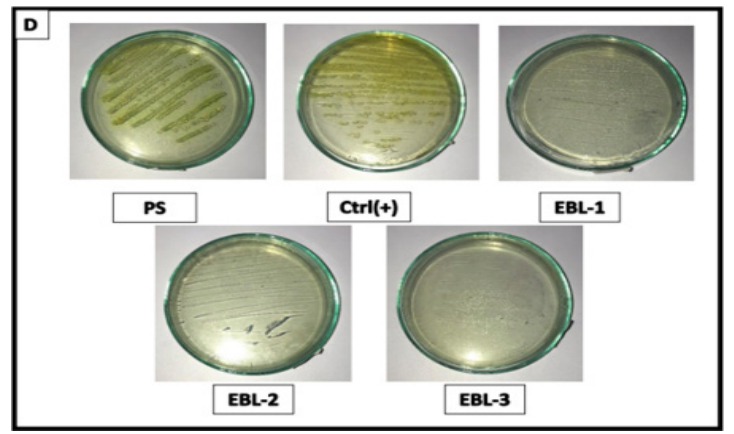

Figure D. Results of the effect of extract basil leaves in minimum bactericidal consentration with broth methods for 24 hours. Ctrl (+); positive controls contained bacteria Pseudomonas aeruginosa and antibiotics, PS; negative controls contained bacteria Pseudomonas aeruginosa only, EBL-1; extract basil leaves with $25 \%$ concentration, EBL2 ; extract basil leaves with $50 \%$ concentration, EBL-3; extract basil leaves with $100 \%$ concentration.

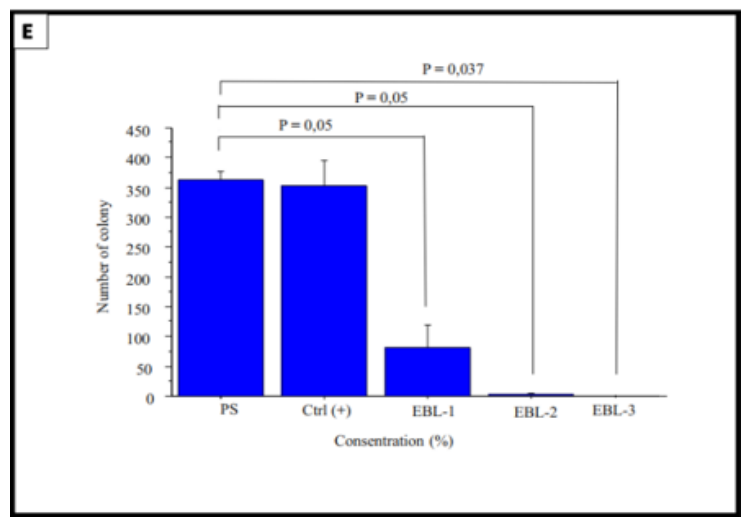

Figure E. Results of statiscticstatistical analysised of the effect of extract basil leaves in minimum bactericidal consentration with broth methods for 8 hours. Ctrl $(+)$; positive controls contained bacteria Pseudomonas aeruginosa and antibiotics, PS; negative controls contained bacteria Pseudomonas aeruginosa only, EBL-1; extract basil leaves with $25 \%$ concentration, EBL-2; extract basil leaves with 50\% concentration, EBL-3; extract basil leaves with $100 \%$ concentration.

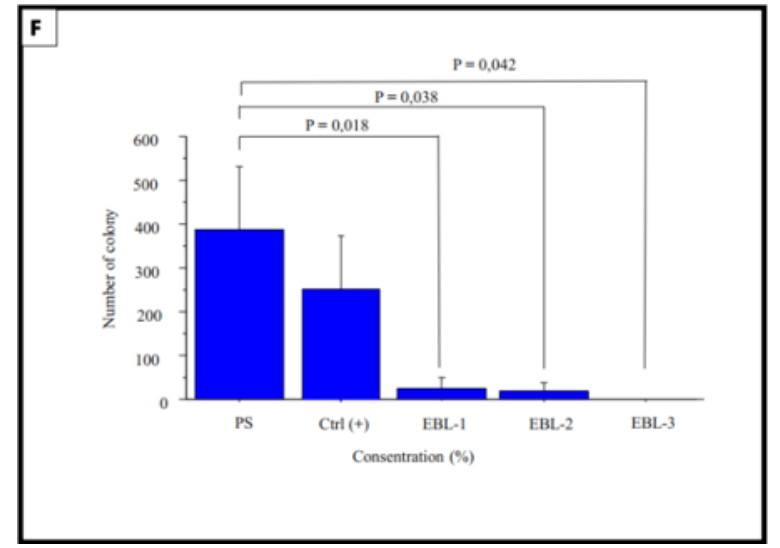

Figure F. Results of statiscticstatistical analysised of the effect of extract basil leaves in minimum bactericidal consentration with broth methods for 24 hours. Ctrl $(+)$; positive controls contained bacteria Pseudomonas aeruginosa and antibiotics, PS; negative controls contained bacteria Pseudomonas aeruginosa only, EBL-1; extract basil leaves with $25 \%$ concentration, EBL-2; extract basil leaves with 50\% concentration, EBL-3; extract basil leaves with $100 \%$ concentration.

\section{Discussion}

In the results of this study, it was found that in broth dilution with 8 hours incubation there was no bacterial growth at all concentrations. Then for 24 hours incubation there was also no bacterial growth at all concentrations. This is in accordance with previous studies that the minimum inhibitory concentration of extract basil leaves on the bacteria Propionibacterium acnes occurred at a concentration of $2 \%{ }^{4}$

Then replanting the plate containing Mueller Hinton agar media so that at all concentrations. The results showed that at 8 hours incubation bacterial growth was still shown in Figures $\mathrm{C}$ and $\mathrm{E}$. This happened because it had not reached the supposed incubation period of 1824 hours. ${ }^{5}$ Nevertheless, this growth occurred in negative controls which only contained bacteria Pseudomonas aeruginosa, positive controls that contained bacteria with antibiotics, and at a concentration of $25 \%$. Meanwhile, at a concentration of $50 \%$ and $100 \%$, the growth of bacteria had begun to be invisible or minimum. Then for the 24hour incubation, bacterial growth was still shown in Figure $\mathrm{D}$ and $\mathrm{F}$. This growth occurred in the negative controls which only contained bacteria Pseudomonas aeruginosa, positive controls that contained bacteria with antibiotics, concentration of $25 \%$, and concentration of $50 \%$. Whereas at a concentration of $100 \%$, bacterial growth did not occur.

From the results of the study, it showed that ethanol extract of basil leaves was effective against the bacteria Pseudomonas aeruginosa in all concentration. It could also kill the growth of Pseudomonas aeruginosa at different concentrations. This is in line with the previous study by Mishra which found basil leaves extract was effective against both gram positive and gram negative bacteria. 6 This ethanol extract of basil leaves was effective because it has antibacterial properties such as alkaloids, tannins, eugenol, and flavonoids. Gram bacteria positive only consists of two layers namely lipopolysaccharide and protein with content lipids by $1 \%-4 \%$. Whereas bacteria gram negative has three layers of peptidoglycan which 
consists of phospholipid, protein, and lipopolysaccharide with a lipid content of $11 \%-22 \%$. This content affects the cell wall of the bacterium Pseudomonas aeruginosa, thus the bacterial cell wall is damaged and inhibits the growth of the bacteria.?

The antibacterial relationship of the ethanol extract of basil leaves has one of the competencies namely eugenol. Eugenol is an antibacterial compound which is a derivative of the class of phenol composition which has the effect of damaging cell membranes. The bond between phenol and bacterial cell walls will activate the permeability of cell membranes and the transportation process, thus bacterial cells will lose cations and macromolecules which cause increased cell growth and death. In high concentrations, it will cause protein to freeze, thus bacterial cells will die. ${ }^{8}$ These results are in accordance with previous studies by Hapsari which used extract basil leaves to effectively inhibit and try to repair Propionibacterium acnes bacteria which is a gram positive bacterial. ${ }^{4}$ The current study by Dev showed the zone diameter of inhibition was $17 \mathrm{~mm}$ due to the action of methanol extract of basil leaves against $S$. aureus and the zone diameter of inhibiting for $S$. typhi was $6 \mathrm{~mm}$, as reported by Joshi, et al. ${ }^{9,10}$

\section{Conclusion}

The extract of basil leaves is effective as a bactericidal to Pseudomonas aeruginosa.

\section{Acknowledgements}

We would like to thank RISTEKDIKTI Indonesia for providing financial support in the "Student Creativity Program" and to Miss Gardina as staff in microbiology laboratory for guiding us in the laboratory.

\section{Conflict of Interest}

The author stated there is no conflict of interest

\section{References}

1. Nugraheni $\mathrm{R}$ and Winarni $\mathrm{S}$. Infeksi Nosokomial di RSUD Setjonegoro Kabupaten Wonosobo. Media Kesehatan Masyarakat Indonesia. 2012; 11: 94-100.

2. Koomanachai P, Tiengrim S, Kiratisin P and Thamlikitkul V. Efficacy and Safety of Colistin (Colistimethate Sodium) For Therapy Of Infections Caused By Multidrug-Resistant Pseudomonas aeruginosa and Acinetobacter baumannii in Siriraj Hospital, Bangkok, Thailand. International Journal of Infectious Diseases. 2007; 11: 402-6.

3. Angelina M, Turnip M and Khotimah S. Uji Aktivitas Antibakteri Ekstrak Etanol Daun Kemangi (Ocimum sanctum L.) terhadap Pertumbuhan Bakteri Escherichia coli dan Staphylococcus aureus. 2015.

4. Hapsari IP. Uji Fitokimia dan Uji Aktivitas Antibakteri Minyak Astri Daun Kemangi (Ocimum basilicum L.) terhadap Pertumbuhan Propionibacterium acnes ATCC 11827 secara In Vitro. Yogyakarta: Universitas Sanata Dharma, 2018.

5. Cockerill F, Clinical and Laboratory Standards I. Performance Standards for Antimicrobial Susceptibility Testing : Twenty-Third Informational Supplement. Wayne, PA: Clinical and Laboratory Standards Institute, 2013.

6. Mishra P and Mishra S. Study of Antibacterial Activity of Ocimum sanctum Extract against Gram Positive and Gram Negative Bacteria. 2011.

7. Summary for Policymakers. In: Intergovernmental Panel on Climate C, (ed.). Climate Change 2013 - The Physical Science Basis: Working Group I Contribution to the Fifth Assessment Report of the Intergovernmental Panel on Climate Change. Cambridge: Cambridge University Press, 2014, p. 1-30.

8. Fauzia RS. Uji Aktivitas Antibakteri Minyak Atsiri Daun Kemangi (Ocimum basilicum L.) terhadap Staphylococcus aureus dan Escherichia coli. 2007.

9. Dev N, Das A, Hossain M and Rahman S. Chemical Compositions of Different Extracts of Ocimum basilicum Leaves. Journal of Scientific Research. 2011; 3: 197-.

10. Joshi S, Jasra WA, Ismail M, Shrestha RM, Yi SL and Wu N. Herders' Perceptions of and Responses to Climate Change in Northern Pakistan. Environmental Management. 2013; 52: 639-48. 